\title{
Aboveground Carbon Storage in Coffee Agroecosystems: The Case of the Central Region of the State of Veracruz in Mexico
}

\author{
Gustavo Celestino Ortiz-Ceballos ${ }^{1}{ }^{(0)}$, Mónica Vargas-Mendoza ${ }^{2}$, Angel Isauro Ortiz-Ceballos ${ }^{3}{ }^{\circledR}$, \\ Martín Mendoza Briseño ${ }^{2}$ and Gustavo Ortiz-Hernández ${ }^{1, * \mathbb{D}}$ \\ 1 Facultad de Ciencias Agrícolas, Universidad Veracruzana, Xalapa 91000, Mexico; gusortiz@uv.mx \\ 2 Colegio de Postgraduados—Campus Veracruz, Veracruz 91700, Mexico; mvargas@colpos.mx (M.V.M.); \\ mmendoza@colpos.mx (M.M.B.) \\ 3 Instituto de Biotecnología y Ecología Aplicada, Universidad Veracruzana, Xalapa 91000, Mexico; \\ angortiz@uv.mx \\ * Correspondence: gustortiz@uv.mx; Tel.: +52-228-842-1749
}

Received: 21 January 2020; Accepted: 5 March 2020; Published: 11 March 2020

\begin{abstract}
This study quantifies the aboveground $C$ storage of coffee agroecosystems (AESs) present in the Xalapa-Coatepec region of the state of Veracruz, one of the most important coffee producing regions in Mexico. We identified and determined the spatial distribution of five different types of coffee AESs. Then, through the point-centered quarter method, we measured canopy coverage, total height, diameter at breast height and density of tree species at 160 randomly selected sampling sites. Using allometric models, we estimated the aboveground biomass and the stored aboveground $C$ by tree species and type of AES; and finally, we scaled up our results at the regional level. We found out that the coffee AESs with the greatest and the lowest potential for storing aboveground $C$ are coffee (Co) + talltrees (tree stratum mainly composed of species taller than $15 \mathrm{~m}$ ) and $\mathrm{Co}+$ AcaciaInga (tree stratum mainly composed by Acacia pennatula), with a carbon density as $73.27 \mathrm{Mg} \mathrm{C}^{-1}$ and $38.47 \mathrm{Mg} \mathrm{C} \mathrm{ha}^{-1}$ respectively. The $91.2 \%$ of the total aboveground $C$ in the studied region is stored by two coffee AES types: Co + talltrees and Co + Inga (tree stratum composed by Inga $s p$.). The aboveground $C$ storage potential of all five coffee AESs in the central region of Veracruz is 2.43 million $\mathrm{MgC}$ with an average carbon density of $55.12 \mathrm{MgC} \mathrm{ha}^{-1}$. These results assert that coffee AESs should be considered important $C$ sinks that contribute to the adaptation and mitigation of climate change.
\end{abstract}

Keywords: carbon; coffee agroecosystems; carbon storage; climate change

\section{Introduction}

The biogeochemical cycle of carbon $(C)$ and its relationship with global warming have occupied the attention of a significant number of researchers worldwide [1-4]. Two topics stand out from the research involving the flow of $\mathrm{C}$ : balance of the global carbon cycle [5] and mitigation of increasing atmospheric $\mathrm{CO}_{2}$ levels through the reduction of emission sources and the increment of $C$ sinks [2,3,6-8].

The world's forests have been estimated to store up to $80 \%$ of all aboveground $C$ and about $40 \%$ of all belowground (soils, litter and roots) terrestrial $C$ [9]. Therefore, deforestation of these ecosystems has significantly modified the global cycle of $C$. The potential of forests for the sequestration of $C$ has been evaluated by several researchers who suggest that forest conservation and sustainable management of agroforestry systems can substantially contribute to the global storage and sequestration of $C$, while providing goods and other environmental services to rural communities in several countries [10-21]. 
Mexico is one of the 14 countries with the highest greenhouse gas emissions; due to the progressive elimination of its forests, it also contributes with $1.5 \%$ of the global emission from fossil energy use [22-24]. Changes in land use in the tropical forests of Mexico are evident; over the period from 1500 to 1985 tropical forests decreased by $80 \%$ and the area of the grasslands increased by $50 \%$ [25]. In Mexico, the average of net $C$ emissions as result of tropical forest conversion to agricultural land, fragmentation of forests and land degradation, was estimated at $20.8 \mathrm{Tg} /$ year [26]. However, if natural areas were protected in Mexico, and also new plantations were restored and established, about 150 million $\mathrm{Mg}$ of $\mathrm{CO}_{2}$ could be mitigated, as estimated in [23]. In Mexico, forest plantations and agroforestry systems represent the greatest potential for the sequestration of $C[14,27,28]$. In that sense, several studies report that the coffee agroecosystem (AES), with diversified shade, has great potential to store and sequester $\mathrm{CO}_{2}$ [22,29-36]. Particularly, in the central region of Veracruz, in Mexico, coffee AESs are the most important agroforestry activity according to land use and other socioeconomic factors. Such AESs are characterized by presenting a diversified tree stratum that provides shade to coffee plants and multiple environmental services to society [25,37-41]. Regarding this subject, several studies show evidence proving that these AESs have high potential for the sequestration and storage of $C[34,35,42-44]$. There also exist some studies that estimate the amount of $C$ stored in the aboveground biomass (leaves, branches and stems) of the tree vegetation present in coffee AESs [45-49]. However, there are no studies focused on classifying aboveground $C$ storage at the regional level and by type of coffee AES. Therefore, this study estimates and compares the potential for $C$ storage in the tree component and also estimates the spatial distribution of $C$ density, for the different types of coffee AES present in the central region of Veracruz, in Mexico.

\section{Methodology}

The study was carried out in the coffee producing region of Xalapa-Coatepec in Veracruz, Mexico, located at $96^{\circ} 47^{\prime}$ and $97^{\circ} 04^{\prime} \mathrm{LN}$ and $19^{\circ} 20^{\prime}$ and $19^{\circ} 38^{\prime} \mathrm{LO}$ (Figure 1 ). The conventional classification of five types of AES coffee was used [50]. This classification is based on the physiognomy and dominance of the species present by type of AES (Table 1). AES 1 represents coffee mainly associated with Acacia pennatula as shade, although other tree and fruit species are present; AES 2 presents a tree component dominated by mango with a second stratum composed mainly of Persian lemon; AES 3 is associated with a tree component dominated by mango with a second stratum comprising different tree and fruit species; the tree component of AES 4 is dominated by Inga sp. associated with other tree and fruit species; finally, AES 5 has a tree stratum where tree species heights are greater than $15 \mathrm{~m}$.

Table 1. Surface and number of sampling points by type of coffee agroecosystem in the central region of Veracruz, México [50].

\begin{tabular}{cccc}
\hline No. & Agroecosystem (AES) & Surface (ha) & Sample Points (n) \\
\hline 1 & Coffee + Acacia + Inga (Co + AcaciaInga) & 3039.25 & 10 \\
2 & Coffee + Mango + Citrus (Co + MaCi) & 564.98 & 9 \\
3 & Coffee + Mango + Others (Co + MaOthers) & 1148.67 & 6 \\
4 & Coffee + Ingas (Co + Inga) & $18,862.87$ & 65 \\
5 & Coffee + Tall trees (Co + Talltrees) & $16,305.56$ & 70 \\
\hline Total & & $39,921.33$ & 160 \\
\hline
\end{tabular}

An ad hoc algorithm programmed in Avenue scripts compatible with ArcView 3.261 GIS (ArcView GIS, 1996) was designed to randomly distribute 160 sampling points within the study area while georeferencing them for early location in the field with a GPS Mca. Garmin 30x (Figure 2). For the distribution of the sampling sites by type of AES, a map with a scale of 1:5000 was used, which shows the spatial distributions of the five types of AES of coffee cultivated by the producers in the study region [50]. Two strata were considered for data collection at each sampling point: the tree stratum is composed of species whose main purpose is to provide shade for coffee plants, and the fruit stratum is 
comprised mainly by an intermediate stratum where fruit species dominate and whose purpose is to diversify production.
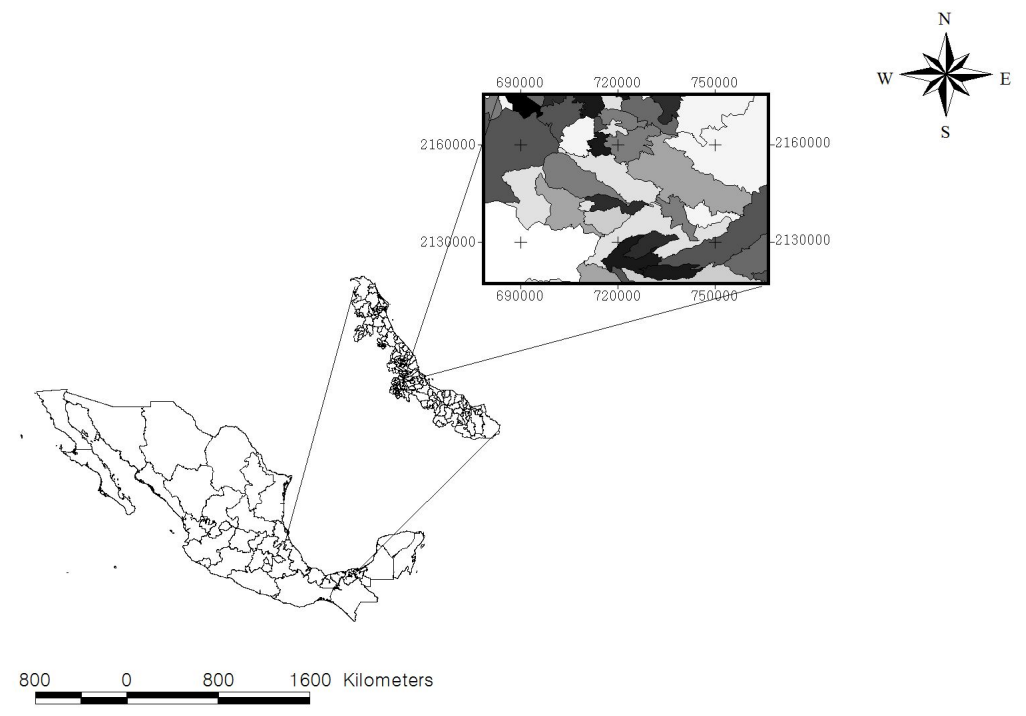

Figure 1. Location of the study site in the central region of the state of Veracruz, México.

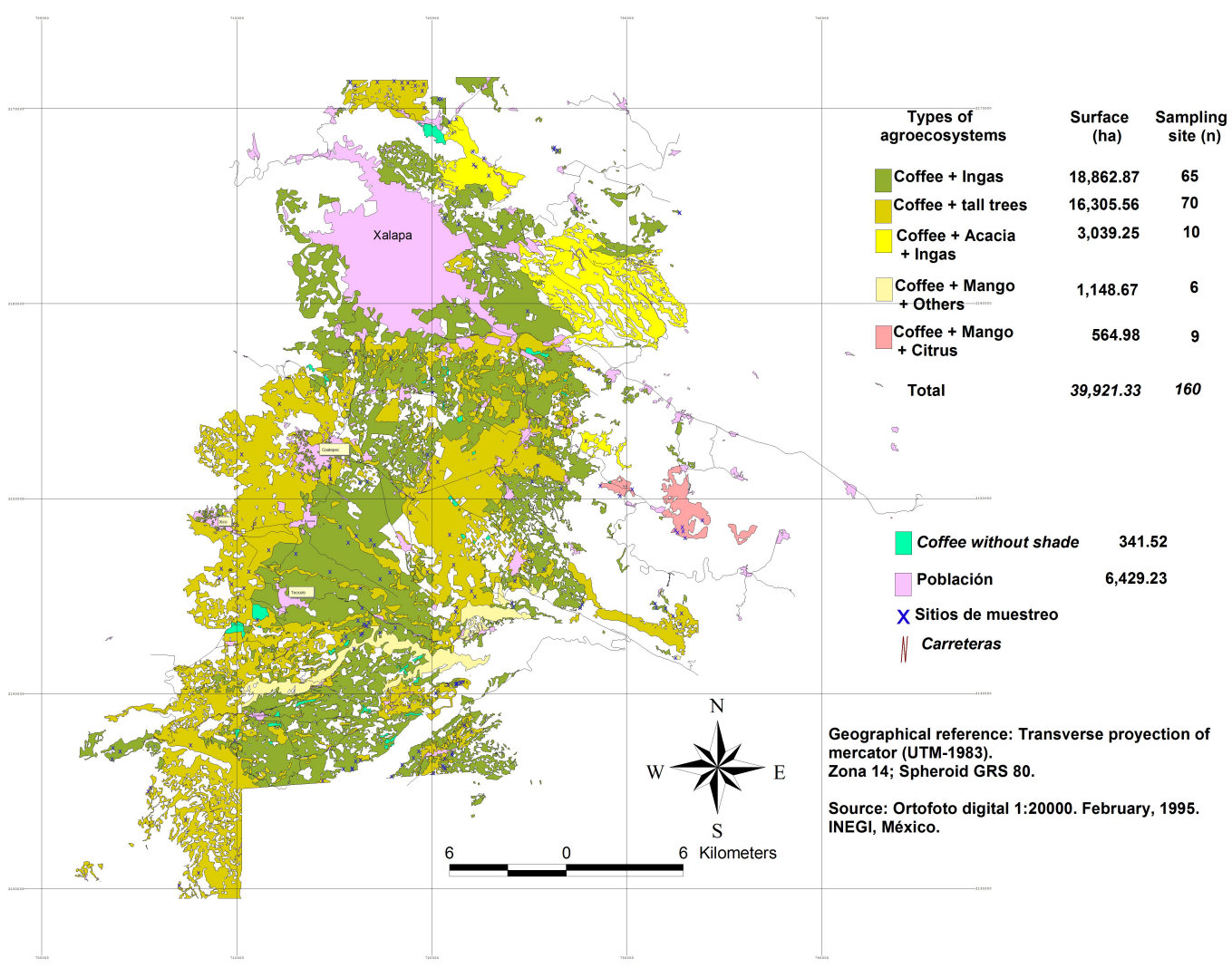

Figure 2. Map showing the spatial distribution of sampling sites by type of coffee agroecosystem in the study region, Veracruz, México.

Subsequently, using the technique of quadrant points [51-53], we identified, for both strata, the species of each tree located at the sampling points, and also measured the diameter at breast height 
(DBH) and the basal diameter by using a diametric tape. Total height was estimated with a PM-5/360 clinometer Mca. Sutton, and coverage (\%) by direct reading in the field [54]. The field data were processed with an ad hoc computer program developed in MS Visual Basic 6.0, designed specifically for this purpose and with which it was feasible to compute the coverage (\%), basal area, above ground biomass (AGB) and $C$ stored for each of tree sampled.

The aboveground biomass (AGB) of each tree was estimated by non-destructive procedures through the application of different allometric models reported in the literature (Table 2). Such models allow one to establish relationships between the AGB and some predictive variable of the vegetation, such as height, DBH or coverage [55-60]. In this study, we used different alometric models with high correlation coefficients ( $R^{2}$ from 0.83 to 0.98 ; see Table 2 ) with predictive variables $\mathrm{DBH}$ and total height, for values of $\mathrm{DBH} \geq 10 \mathrm{~cm}$. The criteria (inclusion-exclusion) to decide whether one of the models would be applied or not to particular species were based on the taxonomic similarity between the species found in this research and the species that the allometric model reports. There were species for which more than one model was applied; in such cases, we used the mean of results obtained by each model, as suggested in [61-66].

In the case of Musa spp., different equations were used to estimate the AGBs of the different reservoirs (leaves, pseudostem and rhizomes) [67]. The aboveground $C$ stored by tree was estimated through multiplying AGB by a factor of 0.5 [68,69]. These results were scaled up at the levels of species (one species is represented by several trees), stratum and type of coffee AES. Then, we estimated the aboveground $C\left(\mathrm{Mg} \mathrm{C} \mathrm{ha}^{-1}\right)$ for each type of AES [13]. Finally, we generated a map showing the spatial distribution of potential $C$ density for each type of coffee AES in the whole study region. We also present descriptive statistics for each type of AES on the distribution and variation of $C$ by species and stratum. A multivariate analysis of variance (MANOVA) was applied to identify statistical significant differences between the aboveground $C$ storage of the distinct coffee AES in the study region (using Wilks statistic with $p<0.05$, and Duncan multirange test for comparison of means with $p<0.05$ ). Statistical analysis was carried out using Statistica software (Stat-Soft, 2017).

Table 2. Allometric models used in the present study for the estimation of aboveground biomass.

\begin{tabular}{|c|c|c|}
\hline Model & $R^{2}$ & Source \\
\hline $\begin{array}{c}\operatorname{Ln}(A G B)=-2.193+2.412 \ln (D B H) \\
D B H=\text { diameter at breast height in } \mathrm{cm} \\
A G B=\text { aboveground biomass in } \mathrm{kg} \mathrm{tree}^{-1}\end{array}$ & 0.9860 & [64] \\
\hline $\begin{array}{c}\operatorname{Ln}(A G B)=-1.969+2.189 \ln (D B H) \\
D B H=\text { diameter at breast height in } \mathrm{cm} \\
A G B=\text { aboveground biomass in } \mathrm{kg} \mathrm{tree}^{-1}\end{array}$ & 0.9750 & [64] \\
\hline $\begin{array}{c}A G B=\exp \left[-3.1141+0.9719 \ln \left(D B H^{2} H\right)\right] \\
D B H=\text { diameter at breast height in } \mathrm{cm} \\
H=\text { tree total height in } \mathrm{m} \\
A G B=\text { aboveground biomass in } \mathrm{kg}^{-1} \text { tree }^{-1}\end{array}$ & 0.9700 & [63] \\
\hline $\begin{array}{c}A G B=46.38055-0.031558 D B H^{2} H \\
D B H=\text { diameter at breast height in } \mathrm{cm} \\
H=\text { tree total height in } \mathrm{m} \\
A G B=\text { aboveground biomass in } \mathrm{kg}^{-1} \text { tree }^{-1}\end{array}$ & - & [65] \\
\hline $\begin{array}{c}\operatorname{Ln}(A G B)=-1.9968+2.4128 \ln (D B H) \\
D B H=\text { diameter at breast height in } \mathrm{cm} \\
A G B=\text { aboveground biomass in } \mathrm{kg} \mathrm{tree}^{-1}\end{array}$ & 0.9840 & [66] \\
\hline $\begin{array}{c}\operatorname{Ln}(A G B)=-1.97414+0.827379 \ln \left(D B H^{2} H\right) \\
D B H=\text { diameter at breast height in } \mathrm{cm} \\
H=\text { tree total height in } \mathrm{m} \\
A G B=\text { aboveground biomass in } \mathrm{kg}^{-1} \text { tree }^{-1}\end{array}$ & 0.8300 & [62] \\
\hline
\end{tabular}


Table 2. Cont.

\begin{tabular}{ccc}
\hline Model & $\boldsymbol{R}^{\mathbf{2}}$ & Source \\
\hline $\operatorname{Ln}(A G B)=-2.25737+0.827843 \ln \left(D B H^{2} H\right)$ & & \\
$D B H=$ diameter at breast height in $\mathrm{cm}$ & 0.8600 & {$[62]$} \\
$H=$ tree total height in $\mathrm{m}$ & & \\
$A G B=$ aboveground biomass in $\mathrm{kg} \mathrm{tree}^{-1}$ & & \\
\hline $\operatorname{Ln}(A G B)=-1.54321+2.247891 \ln D B H$ & & \\
$D B H=$ diameter at breast height in cm & 0.9840 & {$[62]$} \\
$A G B=$ aboveground biomass in $\mathrm{kg} \mathrm{tree}^{-1}$ & & \\
\hline
\end{tabular}

\section{Results and Discussion}

We identified 72 tree species present in shade coffee AES distributed across the study region. The specific richness of coffee AES types is: 57 species in the AES coffee (Co) + Inga, 56 in the AES Co + Talltrees, 23 in the AES Co + AcaciaInga, 20 in the AES Co + MaCi and 15 in the AES Co + MaOthers (Table 3). We estimated an arboreal diversity of 79 species, similarly to what was reported for the Sierra de Atoyac in Veracruz, Mexico, by [70]. Meanwhile, in another study conducted for the central region of the state of Veracruz, 64 species were reported [71]. A similar study about arboreal diversity in the region points out that the agroforestry component in coffee plantations is represented by at least 50 species [25]. Additionally, it is worth mentioning that coffee plantations in the studied area match a priority region for the conservation of mesophyll mountain forest in the country. In this sense, our results assert the importance of coffee plantations grown under shade trees as conservation sites of in situ species, especially those that are native from the tropical montane cloud forest [31,72-74].

Table 3. Density and richness of species identified by type of coffee agroecosystem in the central region of Veracruz, Mexico.

\begin{tabular}{cccccc}
\hline Agroecosystem & Stratum & Density (ind ha $\mathbf{~}^{-\mathbf{1}}$ ) & Species & Surface (ha) & Sample size (n) \\
\hline Co + AcaciaInga & arboreal & 114 & 15 & 3039.25 & 40 \\
& fruit & 73 & 8 & & 40 \\
Co + MaCi & arboreal & 83 & 12 & 564.98 & 32 \\
& fruit & 90 & 8 & & 32 \\
Co + MaOthers & arboreal & 144 & 9 & 1148.67 & 20 \\
& fruit & 159 & 6 & & 24 \\
Co + Inga & arboreal & 184 & 39 & $18,862.87$ & 260 \\
Co + talltrees & fruit & 142 & 18 & & 256 \\
& arboreal & 114 & 40 & $16,305.56$ & 280 \\
& fruit & 73 & 16 & & 280 \\
\hline Total & & & & $39,921.33$ & 1264 \\
\hline
\end{tabular}

\subsection{Content of $C$ by Species and Stratum}

For the tree stratum, the species with the greatest carbon storage potential $\left(>0.5 \mathrm{Mg} C\right.$ tree $\left.^{-1}\right)$ were: Lonchocarpus guatemalensis, Populus mexicana, Oreopanax capitatus, Enterolobium cyclocarpum, Zinowiewia integerrima, Inga jinicuil, Persea americana, Ceiba aesculifolia, Casearia corymbosa, Vismia baccifera, Grevillea robusta and Quercus sp. On the other hand, the species of the same stratum but that showed a storage of $C$ below $0.5 \mathrm{Mg} C$ tree ${ }^{-1}$ are: Tapirira mexicana, Cassia spectabilis, Manilkara zapota, Cedrela odorata, Clethra mexicana and Trema micrantha, among others. This trend is similar to that found in [35], which used allometric models to estimate the biomasses of different species used as shade in coffee plantations in Matagalpa, Nicaragua. The amount of $C$ stored in the aboveground biomass (AGB) in agroforestry systems depends on multiple factors; e.g., quantity of trees present (number of individuals per ha), size of trees, age, density of the wood, number of components, strata and the spatial-temporal location $[75,76]$. The above helps to explain why the same species found in different AESs present 
distinct storage and density amounts of $C$, and the differences between the amount of aboveground $C$ stored by each type of coffee AES, which varies between $38.47 \mathrm{MgC} \mathrm{ha}^{-1}$ and $73.27 \mathrm{Mg} \mathrm{Cha}^{-1}$, with the greatest amount being found in the tree stratum. In that sense, the regional contribution of the species with the greatest carbon storage potential can be reduced if there are few individuals ha ${ }^{-1}$, as in the case of Lonchocarpus guatemalensis, Populus mexicana, Oreopanax capitatus, Ceiba aesculifolia, Casearia corymbosa and Vismia baccifera. However, that is not the case for Inga jinicuil, Enterolobium cyclocarpum and Quercus sp., whose contributions at the regional level turn out to be greater, because they have a greater number of individuals ha ${ }^{-1}$. The results show that the species Inga leptoloba and Inga spuria are species with high planting density and with a wide distribution in all coffee AES since producers prefer them due to their rapid growth, and because they provide a good shade to coffee plants and also represent permanent contribution of litter to the soil that helps improve its fertility [25,38,77]. However, due to their low capacity to store carbon (113.64 and $90.83 \mathrm{~kg} C$ per species, respectively) and compared with other sampled species, they cannot be considered promising species to sequester and store $C$, although this disadvantage can be compensated with other benefits they provide. Individually, some species $\left(\mathrm{kg} \mathrm{C}\right.$ tree $\left.{ }^{-1}\right)$ do not store significant amounts of $C$. However, when their density is estimated, some stand out for their greater contributions; such is the case for Inga spuria, Inga leptoloba, Bursera simaruba, Cupania dentata, Cecropia obtusifolia and Citrus sinensis. However, other species stand out for their contributions in both situations; such is the case for Inga jinicuil, Zinowiewia integerrima, Populus mexicana, Enterolobium cyclocarpum, Lonchocarpus guatemalensis, Grevillea robusta, Oreopanax capitatus, Dendropanax arboreus, Leucaena pulverulenta, Trema micrantha, Cedrela odorata and Liquidambar macrophylla. In the fruit stratum, there are very common species, such as Musa sp, Eriobotrya japonica and Citrus sinensis, but they have low potential to store $C\left(32.61 \mathrm{~kg}^{-1} \mathrm{e}^{-1}\right)$. Others species, such as Mangifera indica (483.24 $\left.\mathrm{kg} \mathrm{tree}^{-1}\right)$, Persea schiedeana $\left(314.46 \mathrm{~kg}\right.$ tree $\left.{ }^{-1}\right)$, Pouteria sapota $\left(336.04 \mathrm{~kg} \mathrm{tree}^{-1}\right)$ and Persea americana $\left(275.63 \mathrm{~kg}\right.$ tree $^{-1}$ ) have a high potential to store $C$, but present lower density because they are species not well accepted by the producers, due to their slow growth, low quality shade and competitiveness for nutrients and water with coffee plants if not handled properly, (Table 4).

Table 4. Average storage of aboveground $C$ by tree $\left(\mathrm{kg}\right.$ tree $\left.{ }^{-1}\right)$ of the most common species found in the study region, Veracruz, México.

\begin{tabular}{lcc}
\hline Species & Frequency & Stored Carbon $\left.\mathbf{( k g ~ C ~ h a ~}{ }^{-1}\right)$ \\
\hline Lonchocarpus guatemalensis & 10 & 2320.47 \\
Enterolobium cyclocarpum & 25 & 1068.18 \\
Zinowiewia integerrima & 9 & 924.89 \\
Inga jinicuil & 68 & 756.32 \\
Quercus sp & 16 & 510.73 \\
Mangifera indica & 87 & 483.24 \\
Tapirira mexicana & 11 & 399.89 \\
Persea schiedeana & 17 & 314.46 \\
Persea americana & 18 & 275.63 \\
Bursera simaruba & 15 & 262.29 \\
Grevillea robusta & 13 & 256.37 \\
Leucaena pulverulenta & 18 & 241.30 \\
Dendropanax arboreus & 16 & 234.82 \\
Trema micrantha & 30 & 210.63 \\
Cecropia obtusifolia & 11 & 130.63 \\
Inga edulis & 15 & 123.63 \\
Inga leptoloba & 63 & 113.63 \\
Inga spuri & 170 & 90.83 \\
Syzygium jambos & 13 & 89.49 \\
Heliocarpus appendiculatus & 12 & 78.93 \\
Citrus sinensis & 117 & 42.01 \\
\hline
\end{tabular}


Table 4. Cont

\begin{tabular}{lcc}
\hline Species & Frequency & Stored Carbon $\left.\mathbf{( k g ~ C ~ h a ~} \mathbf{~ h}^{-1}\right)$ \\
\hline Psidium guajava & 23 & 40.46 \\
Eriobotrya japonica & 55 & 32.61 \\
Citrus reticulata & 22 & 22.67 \\
Citrus latifolia & 16 & 17.48 \\
Musa sapientum & 234 & 3.56 \\
\hline Total & 1264 & 9045.27 \\
\hline
\end{tabular}

\subsection{Storage at the Regional Level and by Type of Agroecosystem}

The results show that the $\mathrm{Co}+\mathrm{MaCi}$ and $\mathrm{Co}+$ Talltrees AES present the species with the highest average values of $C$ storage, and this is because more than $50 \%$ of the sampled species reached $C$ storage greater than $200 \mathrm{~kg}$. The lowest average values corresponded to the $\mathrm{Co}+\mathrm{MaOthers,} \mathrm{Co}+\mathrm{Inga}$ and $\mathrm{Co}+$ AcaciaInga. In the fruit stratum, the highest values are distributed in the $\mathrm{Co}+\mathrm{MaCi}$ and $\mathrm{Co}+\mathrm{MaOthers} \mathrm{AES} \mathrm{(Figure} \mathrm{3)} \mathrm{because} \mathrm{in} \mathrm{these} \mathrm{AES,} \mathrm{the} \mathrm{individuals} \mathrm{of} \mathrm{Mangifera} \mathrm{indica} \mathrm{are} \mathrm{widely}$ distributed with an average value of 429.60 and $767.8 \mathrm{~kg} C$, respectively. The largest carbon storage by type of AES is associated with the presence of trees with higher values in height and DBH; the type of AES that presents individuals with lower carbon storage potential in the tree stratum corresponds to $\mathrm{Co}+$ Inga and $\mathrm{Co}+\mathrm{MaOthers}$, and in the fruit stratum corresponds to $\mathrm{Co}+$ Talltrees, $\mathrm{Co}+$ AcaciaInga and $\mathrm{Co}+$ Inga. The contribution of species depends on their density in each type of AES. The density of $C$ by types of AES shows that with the exception of $\mathrm{Co}+$ MaOthers, the tree stratum always records the highest values (Table 5).

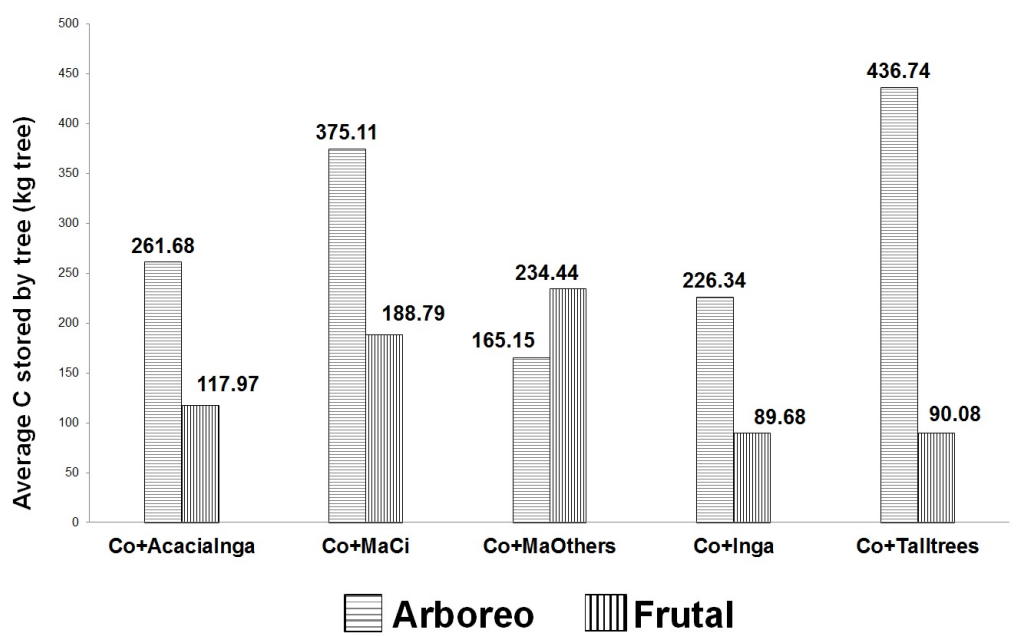

Figure 3. Average $C$ stored by tree $\left(\mathrm{kg} \mathrm{tree}^{-1}\right)$ by stratum and type of coffee agroecosystem.

The density of $C$ ranges from $38.47 \mathrm{MgC} \mathrm{ha}^{-1}$ in the AES de Co + AcaciaInga to $73.27 \mathrm{Mg} \mathrm{C}^{-1}$ for the AES Co + Talltrees, and the average storage value of $C$ in coffee AES is $55.12 \mathrm{Mg} C \mathrm{ha}^{-1}$ (Table 6)—comparable to the results reported by others authors [78-80]. Likewise, another study was conducted on technified agroforestry systems with coffee in the coffee zone of Costa Rica, wherein the reported values varied from 7.5 to $12.5 \mathrm{MgC}^{-1}$ [69]; for the central region of Veracruz, the storage of $C$ reported range from 23.4 to $63.6 \mathrm{Mg} \mathrm{C} \mathrm{ha}^{-1}$ [45], and for the same region, storage values of $C$ in the tree component of coffee agroforestry systems range from 28 to $117 \mathrm{Mg} \mathrm{C} \mathrm{ha-1}$ [54]. These values are consistent with those found in this study. On the other hand, the results show that there are species for shade that reach heights greater than $20 \mathrm{~m}$ and with densities of 7 to 11 individuals ha ${ }^{-1}$ that have high potential to store $C$. However, little is known about their mean annual increment (MAI), wood quality and management; such is the case for palo 
blanco (Zinowiewia integerrima), ixpepel (Trema micrantha), habin (Lonchocarpus guatemalensis), piocho (Melia azedarach), guarumo (Cecropia obtusifolia), quebracho (Cupania dentata), nacaxtle (Enterolobium cyclocarpum), cacao (Tapirira mexicana), nogal (Juglans pyriformis) and jobo (Spondias mombin).

Table 5. Total $C$ stored in the aboveground by type of coffee agroecosystem in the study region Veracruz, México. AES = agroecosystem; $\mathrm{ACT}=$ average Carbon by tree; $\mathrm{ACD}=$ aboveground carbon density; TCAAS = total aboveground Carbon by agroecosystem and stratum; TCAA = total aboveground Carbon by agroecosystem for the entire region.

\begin{tabular}{lcccccccc}
\hline AES & Stratum & Species & $\begin{array}{c}\text { ACT } \\
\mathbf{~ k g}\end{array}$ & $\begin{array}{c}\text { Trees } \\
\text { Ind } \mathbf{h a}^{-1}\end{array}$ & $\begin{array}{c}\text { ACD } \\
\mathbf{M g} \cdot \mathbf{C} \cdot \mathbf{h a}^{-1}\end{array}$ & $\begin{array}{c}\text { Surface } \\
\text { ha }\end{array}$ & $\begin{array}{c}\text { TCAAS } \\
\mathbf{M g} \cdot \mathbf{C}\end{array}$ & $\begin{array}{c}\text { TCAA } \\
\mathbf{M g} \cdot \mathbf{C}\end{array}$ \\
\hline Co+AcaciaInga & arboreal & 15 & 261.67 & 114 & 29.86 & 3039.25 & $90,752.01$ & $116,919.25$ \\
& fruit & 8 & 117.97 & 73 & 8.61 & 3039.25 & $26,167.94$ & \\
Co+MaCi & arboreal & 12 & 375.10 & 83 & 31.17 & 564.98 & $17,610.43$ & $27,243.34$ \\
& fruit & 8 & 188.78 & 90 & 17.05 & 564.98 & 9632.91 & \\
Co+MaOthers & arboreal & 9 & 165.15 & 144 & 23.80 & 1148.67 & $27,338.35$ & $70,367.52$ \\
& fruit & 6 & 234.43 & 159 & 37.46 & 1148.67 & $43,029.18$ & \\
Co+Inga & arboreal & 39 & 226.34 & 184 & 41.67 & $18,862.87$ & $786,007.46$ & $1,026,708.25$ \\
& fruit & 18 & 89.67 & 142 & 12.73 & $18,862.87$ & $240,121.22$ & \\
Co+talltrees & arboreal & 40 & 436.74 & 143 & 62.63 & $16,305.56$ & $1,021,217.22$ & $1,194,708.38$ \\
& fruit & 16 & 118.14 & 118 & 10.64 & $16,305.56$ & $173,491.16$ & \\
\hline Total & & & & & & $39,921.33$ & $2,435,368.44$ & $2,435,368.44$ \\
\hline
\end{tabular}

Table 6. Density of aboveground $C\left(\mathrm{MgC} \mathrm{ha}^{-1}\right)$ by type of coffee agroecosystem in the study region Veracruz, Xalapa.

\begin{tabular}{lccc}
\hline \multirow{2}{*}{ Agroecosystem } & \multicolumn{3}{c}{ Carbon Density $\left(\mathrm{Mg} \mathrm{C}\right.$ ha $\left.^{-1}\right)$} \\
& Arboreal & Fruit & Total \\
\hline Co + Inga & 41.67 & 12.73 & 54.4 \\
Co + talltrees & 62.63 & 10.64 & 73.27 \\
Co + MaOthers & 23.80 & 37.46 & 61.26 \\
Co + MaCi & 31.17 & 17.05 & 48.22 \\
Co + AcaciaInga & 29.86 & 8.61 & 38.47 \\
\hline Mean & 37.83 & 17.30 & 55.12 \\
\hline
\end{tabular}

The estimation of the $C$ storage above ground in the AES show that for the tree stratum, the greatest potential is found in the Co + Talltrees and Co + Inga AES, and the lowest potentials were found for the AES Co + MaOthers and Co + AcaciaInga; in the fruit stratum, the AES with the highest storage corresponds to Co + MaOthers. In summary, if a strategy for the conservation of the coffee agroecosystems in the Xalapa-Coatepec region was implemented, there would be an estimated potential for storing $C$ of 2,435,368.44 $\mathrm{Mg} C$ in 39,921.33 ha.

Regarding the spatial distribution of $C$ contents by type of AES and $C$ densities, it is noted that the highest densities are around the town of Cosautlán and the small town of Chavarillo and the entire central portion of the studied region that is covered by the AES Co + Inga, whereas the regions of lower density are located in the northern part of Xalapa and the towns of El Castillo, Chiltoyac and 6 de Enero colony (Figure 4).

Despite the potential of coffee AES to store $C$, the fact of maintaining its updated long-term conservation scheme is uncertain because coffee production is currently not economically viable, although environmentally it is the most appropriate. This uncertainty is based on the international variation of coffee prices, the high incidence of rust and growth of urban sprawl in areas dedicated to produce coffee, among other problems. Therefore, some of the most important leaks that are glimpsed nowadays and which put at risk the permanence of coffee AES in the studied region, are the transformation of coffee AES into fields of sugarcane cultivation, the growth of urban sprawl in the outskirts of the main cities (stimulated by the creation of country-house type units) and the probable negative impacts of climate change [81]. 


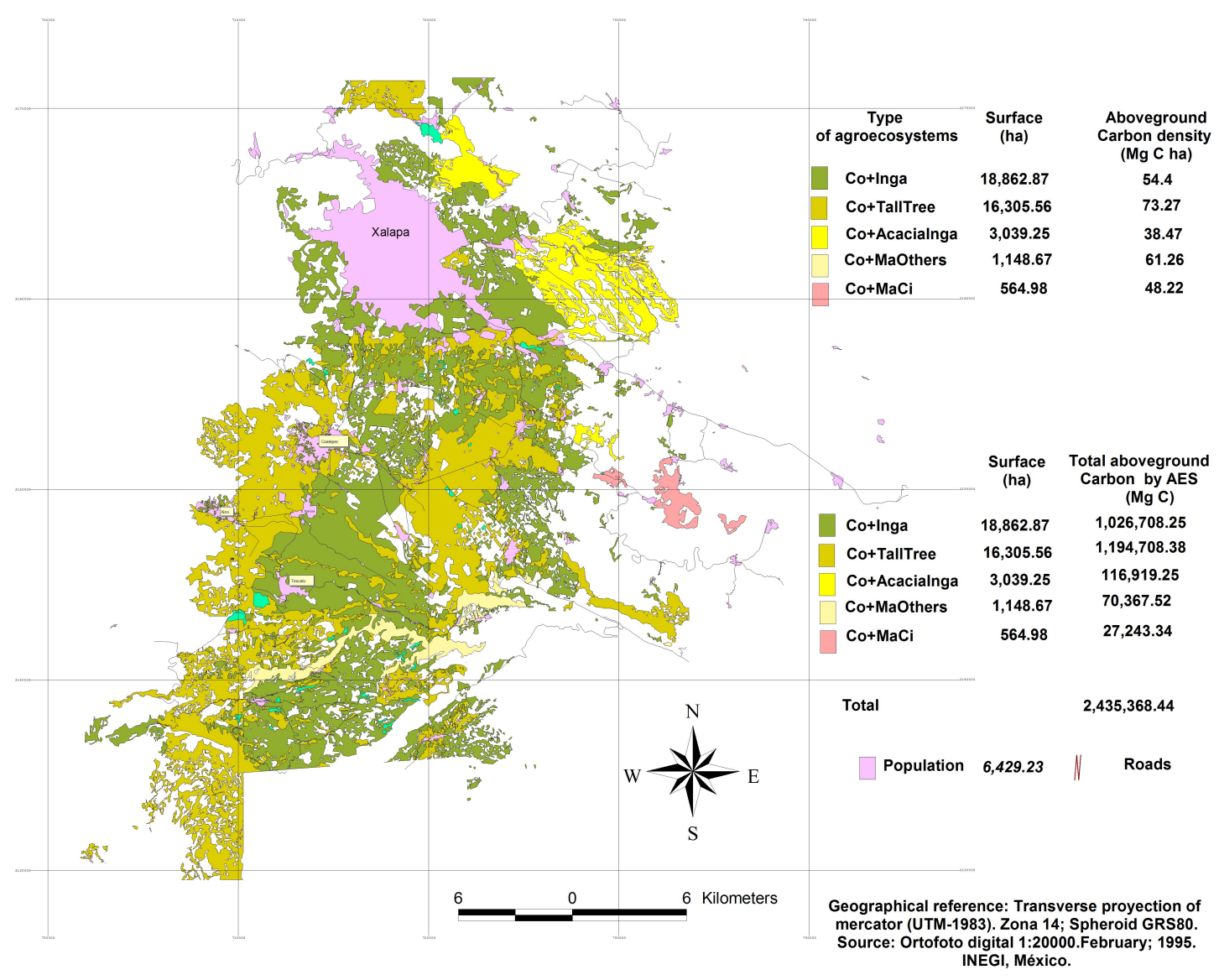

Figure 4. Spatial distribution of $C$ density $\left(\mathrm{Mg} \mathrm{C} \mathrm{ha}^{-1}\right)$ by type of coffee agroecosystem (AES) in the central region of the state of Veracruz, Mexico.

Although this study was limited to the estimation of current aboveground carbon storage in coffee AES, its results confirm the importance of carrying out future research towards the estimation of $C$ storage in other reservoirs, such as roots, mulch and soil, and the measurement of $\mathrm{CO}_{2}$ fluxes (respiration and photosynthesis) in order to allow for the design of models to predict future scenarios that help to explain the carbon balance in the region of study. Moreover, the research should support the importance of preserving coffee AES for the mitigation and adaptation to climate change.

The results of the present research suggest the encouragement of creating a scenario for the preservation of the coffee AES providing a management of the tree component compatible with coffee production oriented to the development of agroforestry systems that can be economically viable and socially acceptable. They also suggest promoting the preservation and improvement of coffee plantations with diversified shade in order to increase the capture of $C$, and generate added value thanks to wood and other forest products, while reducing the aforementioned leaks. In that sense, in accordance with [82], the results of this study allow us to recommend the use of timber species for shade, and gradually to replace those species of low economic value and low $C$ storage for others with greater potential for capturing and storing $C$, preferably with local species of proven quality, such as the hormiguillo (Cordia alliodora), cedro (Cedrela odorata), nacaxtle (Enterolobium cyclocarpum) and gravilea (Grevillea robusta), in order to also ensure profits from wood sale. It is even possible to use other species, such as palo blanco (Zinowiewia integerrima), ixpepel (Trema micrantha), guarumo (Cecropia obtusifolia), quebracho (Cupania dentata), encino (Quercus sp) and cedro-nogal (Juglans pyriformis), whose economical importance and wood quality would have to be studied.

Finally, it is important to highlight that allometric models are an essential tool for understanding $C$ storage and fluxes in tropical forests and agroforestry systems [56-59,75]. We confirmed predictive 
power of allometric models, since the aboveground $C$ amounts estimated in this paper are consistent with those reported by other studies carried out at the plot level $[58,83]$. We highlight that our study contributes to reach a regional level perspective on the potential of coffee AES for the mitigation and adaptation of climate change. However, we agree to the importance of evaluating the accuracy of these models and others, including new data of different geographical locations and types of AES [84-87].

\section{Conclusions}

The tree species with the greatest potential for storing $C$ in aboveground are Lonchocarpus guatemalensis, Populus mexicana, Oreopanax capitatus, Enterolobium cyclocarpum and Zinowiewia integerrima, while the largest contribution per unit area belongs to Inga sp., due to its high density and wide distribution along the coffee AES.

The largest storage of above ground $C$ in the coffee AES is found at the tree stratum, and in a smaller proportion, in the fruit stratum. The AES Co + MaOthers shows high levels in its fruit stratum due to the presence of mango species (Mangifera indica), which actually plays the role of the tree stratum. The average of aboveground $C$ storage of the five coffee AES turned out to be $55.12 \mathrm{Mg} C \mathrm{ha}^{-1}$. The highest $C$ density corresponded to the AES Co + Talltrees with $73.27 \mathrm{Mg} \mathrm{C}^{-1}$, while the lowest value was for Co + Acacia + Ingas with $38.47 \mathrm{MgC} \mathrm{ha}{ }^{-1}$.

The potential storage of $C$ in the coffee AES of the Xalapa-Coatepec region is 2.4 million $\mathrm{Mg}$ distributed across an area of 39,921.33 ha. Because of the extension they cover and their strategic geographical distribution in the central region of Veracruz, it is strongly suggested that these coffee AES be considered as sinks of $C$.

We highlight the importance of carrying out future research aimed to: (i) estimate the $C$ storage in other sinks, such as roots, soil, leaf litter, weeds and epiphytes; (ii) consider the dynamics of $C$ sequestration; and (iii) establish a baseline for identifying and analyzing possible leaks.

This study shows the importance of valuing coffee AES with shade present at the Xalapa-Coatepec region, in other regions of Mexico, and in the world as true $C$ sinks and other environmental services providers. Thus, to argue the creation of programs focused on sensitizing the society and proper institutions in order to promote their conservation.

Author Contributions: Conceptualization and research design, G.C.O.-C. and M.V.-M.; software and algorithm design, G.O.-H.; formal analysis, G.C.O.-C.; investigation and fieldwork, G.C.O.-C.; writing-original draft preparation, G.C.O.-C. and A.I.O.-C; writing-review and editing, G.O.-H and M.M.B. and A.I.O.-C. All authors have read and agreed to the published version of the manuscript.

Funding: This research received no external funding.

Acknowledgments: Thanks to M.C. Agustín Muñoz-Ceballos for his important help to improve the quality of the figures in this paper.

Conflicts of Interest: The authors declare no conflict of interest.

\section{References}

1. Caro, D.; Davis, S.J.; Bastianoni, S.; Caldeira, K. Global and regional trends in greenhouse gas emissions from livestock. Clim. Chang. 2014, 126, 203-216. [CrossRef]

2. Field, C.B.; Barros, V.R.; Dokken, D.; Mach, K.; Mastrandrea, M.; Bilir, T.; Chatterjee, M.; Ebi, K.; Genova, R.; Yohe, G.W. IPCC 2014: Summary for Policymakers in Climate Change 2014: Impacts, Adaptation, and Vulnerability. Part A: Global and Sectoral Aspects. Contribution of Working Group II to the Fifth Assessment Report of the Intergovernmental Panel on Climate Change; Technical Report; IPCC: Geneva, Switzerland, 2014.

3. Phillips, O.L.; Malhi, Y.; Higuchi, N.; Laurance, W.F.; Núñez, P.V.; Vásquez, R.M.; Laurance, S.G.; Ferreira, L.V.; Stern, M.; Brown, S.; et al. Changes in the carbon balance of tropical forests: Evidence from long-term plots. Science 1998, 282, 439-442. [CrossRef]

4. De Jong, B.; Anaya, C.; Masera, O.; Olguín, M.; Paz, F.; Etchevers, J.; Martínez, R.D.; Guerrero, G.; Balbontín, C. Greenhouse gas emissions between 1993 and 2002 from land-use change and forestry in Mexico. For. Ecol. Manag. 2010, 260, 1689-1701. [CrossRef] 
5. Watson, R.; Meira Filho, L.; Sanhueza, E.; Janetos, A. Greenhouse gases: Sources and sinks. Clim. Chang. 1992, 92, 25-46.

6. Stocker, T.; Qin, D.; Plattner, G.; Tignor, M.; Allen, S.; Boschung, J.; Nauels, A.; Xia, Y.; Bex, V.; Midgley, P. Summary for policymakers Climate change 2013: The physical science basis. In Contribution of Working Group I to the Fifth Assessment Report of the Intergovernmental Panel on Climate Change; IPCC: Geneva, Switzerland, 2013.

7. Trexler, M.C.; Haugen, C. Keeping It Green: Tropical Forestry Opportunities for Mitigating Climate Change; Number F/333.7516 T7; World Resources Institute: Washington, DC, USA, 1995.

8. Schimel, D.S. Terrestrial ecosystems and the carbon cycle. Glob. Chang. Biol. 1995, 1, 77-91. [CrossRef]

9. Dixon, R.K.; Solomon, A.; Brown, S.; Houghton, R.; Trexier, M.; Wisniewski, J. Carbon pools and flux of global forest ecosystems. Science 1994, 263, 185-190. [CrossRef] [PubMed]

10. Pompa-García, M.; Sigala-Rodríguez, J.Á. Variación de captura de carbono de especies forestales en México: Una revisión. Madera Y Bosques 2017, 23, 225-235.

11. Pompa-Garcia, M.; Sigala-Rodríguez, J.A.; Jurado, E.; Flores, J. Tissue carbon concentration of 175 Mexican forest species. IFor-Biogeosci. For. 2017, 10, 754. [CrossRef]

12. Orihuela-Belmonte, D.; De Jong, B.; Mendoza-Vega, J.; Van der Wal, J.; Paz-Pellat, F.; Soto-Pinto, L.; Flamenco-Sandoval, A. Carbon stocks and accumulation rates in tropical secondary forests at the scale of community, landscape and forest type. Agric. Ecosyst. Environ. 2013, 171, 72-84. [CrossRef]

13. De Jong, B.H. Forestry for Mitigating the Greenhouse Effect: An Ecological and Economic Assessment of the Potential of Land Use to Mitigate $\mathrm{CO}_{2}$ Emissions in the Highlands of Chiapas, Mexico; Instituto Nacional de Ecología: Mexico City, Mexico, 2000; pp. 220-230.

14. Cairns, M.; Barker, J.; Shea, R.; Haggerty, P. Carbon dynamics of Mexican tropical evergreen forests: Influence of forestry mitigation options and refinement of carbon-flux estimates. Interciencia Caracas 1995, 20, 401-408.

15. Dixon, R.K.; Winjum, J.K.; Andrasko, K.J.; Lee, J.J.; Schroeder, P.E. Integrated land-use systems: Assessment of promising agroforest and alternative land-use practices to enhance carbon conservation and sequestration. Clim. Chang. 1994, 27, 71-92. [CrossRef]

16. Masera, O.R. Carbon mitigation scenarios for Mexican forests: Methodological considerations and results. Interciencia 1995, 20, 388-436.

17. Brown, S.; Lugo, A.E. Aboveground biomass estimates for tropical moist forests of the Brazilian Amazon. Interciencia Caracas 1992, 17, 8-18.

18. Makundi, W.; Sathaye, J.; Fearnside, P. Carbon Emissions and Sequestration in Forests: Case Studies from Seven Developing Countries; Technical Report; Lawrence Berkeley Lab. Environmental Protection Agency: Berkeley, CA, USA, 1992.

19. Houghton, R.; Unruh, J.; Lefebvre, P. Current land cover in the tropics and its potential for sequestering carbon. Glob. Biogeochem. Cycles 1993, 7, 305-320. [CrossRef]

20. Myers, N. The greenhouse effect: A tropical forestry response. Biomass 1989, 18, 73-78. [CrossRef]

21. Sedjo, R.A.; Solomon, A.M. Climate and forests. Greenh. Warm. Abat. Adapt. 1989, 3, 105-120.

22. Mora, F.; Jaramillo, V.J.; Bhaskar, R.; Gavito, M.; Siddique, I.; Byrnes, J.E.; Balvanera, P. Carbon accumulation in Neotropical dry secondary forests: The roles of forest age and tree dominance and diversity. Ecosystems 2018, 21, 536-550. [CrossRef]

23. Gay, C.; Martínez, J. Mitigation of emissions of greenhouse gases in Mexico. Interciencia-Caracas 1995, $20,336-342$.

24. Detwiler, R.P.; Hall, C.A. Tropical forests and the global carbon cycle. Science 1988, 239, 42-47. [CrossRef]

25. López-Morgado, R.; Díaz-Padilla, G.; Salazar-García, G.; García-Mayoral, L.E.; Guajardo-Panes, R. Desarrollo y medio ambiente en México: Diganóstico; Friedrich Ebert Stiftung Eds.; Fundación Universo Veintiuno: Mexico City, México, 1990; 165p.

26. Riley, R. The Contribution of Forest Land Use to Total National Carbon Flux: Case Studies in the Former Soviet Union, United States, Mexico, and Brazil; EPA/600/R-95/044; United States Environmental Protection Agency: Washington, DC, USA, 1995.

27. Casanova-Lugo, F.; Ramírez-Avilés, L.; Parsons, D.; Caamal-Maldonado, A.; Piñeiro-Vázquez, A.T.; Díaz-Echeverría, V. Environmental services from tropical agroforestry systems. Rev. Chapingo. Ser. Cienc. For. Y Del Ambiente 2016, 22, 269-284. [CrossRef]

28. Beer, J.; Harvey, C.; Ibrahim, M.; Harmand, J.M.; Somarriba, E.; Jiménez, F. Servicios ambientales de los sistemas agroforestales. Agroforestería En Las Américas 2003, 10, 80-87. 
29. Ruelas-Monjardín, L.C.; Nava-Tablada, M.E.; Cervantes, J.; Barradas, V.L. Importancia ambiental de los agroecosistemas cafetaleros bajo sombra en la zona central montañosa del estado de Veracruz, México. Madera Y Bosques 2014, 20, 27-40. [CrossRef]

30. Van Rikxoort, H.; Schroth, G.; Läderach, P.; Rodríguez-Sánchez, B. Carbon footprints and carbon stocks reveal climate-friendly coffee production. Agron. Sustain. Dev. 2014, 34, 887-897. [CrossRef]

31. Toledo, V.M.; Moguel, P. Coffee and sustainability: The multiple values of traditional shaded coffee. J. Sustain. Agric. 2012, 36, 353-377. [CrossRef]

32. De Souza, H.N.; de Goede, R.G.; Brussaard, L.; Cardoso, I.M.; Duarte, E.M.; Fernandes, R.B.; Gomes, L.C.; Pulleman, M.M. Protective shade, tree diversity and soil properties in coffee agroforestry systems in the Atlantic Rainforest biome. Agric. Ecosyst. Environ. 2012, 146, 179-196. [CrossRef]

33. Mena Mosquera, V.E. Relation between the Carbon Stored in the Biomass and the Physiognomic Composition of the Vegetation in the Agroforestry Systems with Coffee and in Secondary Forests of the Volcánica Central-Talamanca Biological Corridor in Costa Rica. Ph.D. Thesis, CATIE, Turrialba, Costa Rica, October 2008.

34. Peña del Valle, A.; Pérez Haro, E.; Pérez Samayoa, I. Café Sustentable y Bonos de Carbono; El cafetal del futuro; Shaker Verlag: Aachen, Germany, 2006; pp. 333-360.

35. Segura, M.; Kanninen, M.; Suárez, D. Allometric models for estimating aboveground biomass of shade trees and coffee bushes grown together. Agrofor. Syst. 2006, 68, 143-150. [CrossRef]

36. Soto Pinto, L.; De Jong, B.; Esquivel Bazán, E.; Quechulpa, S. Potencial Ecológico y Económico de Captura de Carbono en Cafetales; El cafetal del futuro: Realidades y visiones; Shaker: Aachen, Germany, 2006; pp. 333-360.

37. García, C. Identificación de Cafetales de Sombra Jugando un Papel Sobresaliente en la Conservación de la Biodiversidad en el Centro del Estado de Veracruz; Escuela de Biología, BUAP: Puebla, Mexico, 2015.

38. Escamilla Prado, E. El Café Cereza en México: Tecnología de la Producción; Number 633.73972 E74, Universidad Autónoma Chapingo, Centro de Investigaciones: Chapingo, Mexico, 1993.

39. López-Morgado, R.; Contreras, A.; Ruiz, J.; Castillo, G.; Martínez-Rodríguez, J. Diagnóstico de la Cafeticultura en la Zona Centro del Estado de Veracruz; Décima Segunda Reunión Científica-Tecnológica Forestal y Agropecuaria; INIFAP: Veracruz, México, 1999.

40. Manson, R.H. Agroecosistemas Cafetaleros de Veracruz: Biodiversidad, Manejo y Conservación; Instituto Nacional de Ecología: Mexico City, Mexico, 2008; pp. 223-234.

41. Mokondoko, P.; Manson, R.H.; Pérez-Maqueo, O. Assessing the service of water quality regulation by quantifying the effects of land use on water quality and public health in central Veracruz, Mexico. Ecosyst. Serv. 2016, 22, 161-173. [CrossRef]

42. Pineda-López, M.; Ortiz-Ceballos, G.; Sánchez-Velásquez, L.R. Los cafetales y su papel en la captura de carbono: Un servicio ambiental aún no valorado en Veracruz. Madera Y Bosques 2005, 11, 3-14.

43. Hergoualch, K.; Blanchart, E.; Skiba, U.; Hénault, C.; Harmand, J.M. Changes in carbon stock and greenhouse gas balance in a coffee (Coffea arabica) monoculture versus an agroforestry system with Inga densiflora, in Costa Rica. Agric. Ecosyst. Environ. 2012, 148, 102-110. [CrossRef]

44. Lorenz, K.; Lal, R. Soil organic carbon sequestration in agroforestry systems. A review. Agron. Sustain. Dev. 2014, 34, 443-454. [CrossRef]

45. Dávalos, R.; Rodrigues, M.; Martínez, E. Almacenamiento de carbono; Manson, R., Hernández, V., Gallina, S., Mehltreter, K., Eds.; INECOL-SERMANAT: Xalapa, México, 2008; pp. 223-234.

46. De Miguel Magana, S.; Harmand, J.M.; Hergoualc'h, K. Cuantificación del carbono almacenado en la biomasa aérea y el mantillo en sistemas agroforestales de café en el suroeste de Costa Rica. Agroforestería En Las Américas 2004, 11, 98-104.

47. Negash, M.; Kanninen, M. Modeling biomass and soil carbon sequestration of indigenous agroforestry systems using CO2FIX approach. Agric. Ecosyst. Environ. 2015, 203, 147-155. [CrossRef]

48. Soto-Pinto, L.; Aguirre-Dávila, C.M. Carbon stocks in organic coffee systems in Chiapas, Mexico. J. Agric. Sci. 2015, 7, 117. [CrossRef]

49. Soto-Pinto, L.; Anzueto, M.; Mendoza, J.; Ferrer, G.J.; de Jong, B. Carbon sequestration through agroforestry in indigenous communities of Chiapas, Mexico. Agrofor. Syst. 2010, 78, 39. [CrossRef]

50. Ortiz Ceballos, G. El Agroecosistema Café: Crisis de Mercado y Sustentabilidad. Ph.D. Thesis, Colegio de Posgraduados, Veracruz, México, January 2004. 
51. Sánchez-Velásquez, L.R.; Lóopez, R.P. Ecología Cuantitativa en Plantas; Universidad de Guadalajara: Guadalajara, Mexico, 2000.

52. Magurran, A.E. Ecological Diversity and Its Measurement; Princeton University Press: Princeton, NJ, USA, 1988.

53. Mueller-Dombois, D.; Ellenberg, H. Aims and Methods of Vegetation Ecology; John Wiley and Sons: New York, NY, USA, 1974; p. 347.

54. Espinoza-Domínguez, W.; Krishnamurthy, L.; Vázquez-Alarcón, A.; Torres-Rivera, A. Almacén de carbono en sistemas agroforestales con café. Rev. Chapingo Ser. Cienc. For. del Ambiente 2012, 18, 57-70. [CrossRef]

55. Basuki, T.; Van Laake, P.; Skidmore, A.; Hussin, Y. Allometric equations for estimating the above-ground biomass in tropical lowland Dipterocarp forests. For. Ecol. Manag. 2009, 257, 1684-1694. [CrossRef]

56. Alvarez, E.; Duque, A.; Saldarriaga, J.; Cabrera, K.; de Las Salas, G.; del Valle, I.; Lema, A.; Moreno, F.; Orrego, S.; Rodríguez, L. Tree above-ground biomass allometries for carbon stocks estimation in the natural forests of Colombia. For. Ecol. Manag. 2012, 267, 297-308. [CrossRef]

57. Chave, J.; Réjou-Méchain, M.; Búrquez, A.; Chidumayo, E.; Colgan, M.S.; Delitti, W.B.; Duque, A.; Eid, T.; Fearnside, P.M.; Goodman, R.C. Improved allometric models to estimate the aboveground biomass of tropical trees. Glob. Chang. Biol. 2014, 20,3177-3190. [CrossRef]

58. Picard, N.; Rutishauser, E.; Ploton, P.; Ngomanda, A.; Henry, M. Should tree biomass allometry be restricted to power models? For. Ecol. Manag. 2015, 353, 156-163. [CrossRef]

59. Duque, A.; Saldarriaga, J.; Meyer, V.; Saatchi, S. Structure and allometry in tropical forests of Chocó, Colombia. For. Ecol. Manag. 2017, 405, 309-318. [CrossRef]

60. Hao, H.; Li, W.; Zhao, X.; Chang, Q.; Zhao, P. Estimating the Aboveground Carbon Density of Coniferous Forests by Combining Airborne LiDAR and Allometry Models at Plot Level. Front. Plant Sci. 2019, 10, 917. [CrossRef] [PubMed]

61. Acosta-Mireles, M.; Vargas Hernandez, J.; Velázquez-Martínez, A.; Etchevers-Barra, J. Estimación de la biomasa aérea mediante el uso de relaciones alométricas en seis especies arboreas en oaxaca, México. Agrociencia 2002, 36, 725-736.

62. Campbell, J.S.; Lieffers, V.J.; Pielou, E. Regression equations for estimating single tree biomass of trembling aspen: Assessing their applicability to more than one population. For. Ecol. Manag. 1985, 11, 283-295. [CrossRef]

63. Brown, S.; Gillespie, A.J.; Lugo, A.E. Biomass estimation methods for tropical forests with applications to forest inventory data. For. Sci. 1989, 35, 881-902.

64. Ter-Mikaelian, M.T.; Korzukhin, M.D. Biomass equations for sixty-five North American tree species. For. Ecol. Manag. 1997, 97, 1-24. [CrossRef]

65. Parresol, B.R. Assessing tree and stand biomass: A review with examples and critical comparisons. For. Sci. 1999, 45, 573-593.

66. Nelson, B.W.; Mesquita, R.; Pereira, J.L.; De Souza, S.G.A.; Batista, G.T.; Couto, L.B. Allometric regressions for improved estimate of secondary forest biomass in the central Amazon. For. Ecol. Manag. 1999, 117, $149-167$. [CrossRef]

67. Jimenez Avila, E.; Martinez Vara, P. Estudios ecologicos del agroecosistema cafetalero. II. Produccion de materia organica en diferentes tipos de estructura. Biotica 1979, 4, 109-116.

68. Montoya, G.; Soto, L.; de Jong, B.; Nelson, K.; Farias, P.; Yakactic, P.; Taylor, J.H.; Tipper, R. Desarrollo forestal sustentable: Captura de carbono en las zonas tzeltal y tojolabal del estado de Chiapas. Cuad. De Trab. 1995, 4, 80.

69. Ávila, G.; Jiménez, F.; Beer, J.; Gómez, M.; Ibrahim, M. Almacenamiento, fijación de carbono y valoración de servicios ambientales en sistemas agroforestales en Costa Rica. Agroforestería En Las Américas 2001, 8, $32-35$.

70. García Mayoral, L.E.; Valdez Hernández, J.I.; Luna Cavazos, M.; López Morgado, R. Estructura y diversidad arbórea en sistemas agroforestales de café en la Sierra de Atoyac, Veracruz. Madera y Bosques 2015, 21, 69-82. [CrossRef]

71. Zamora, A.G.; Rodríguez, M.E.; Barradas, V.L. Mountain cloud forest and grown-shade coffee plantations: A comparison of tree biodiversity in central Veracruz, Mexico. For. Syst. 2016, 25, 10.

72. Toledo-Aceves, T. Regiones prioritarias para la conservación del bosque mesófilo de montaña. AGROProductividad 2017, 10, 10-14. 
73. Sosa-Fernández, V.; López-Morgado, R.; Toledo-Aceves, T.; Bárcenas-Pazos, G. Oportunidades de conservación del bosque de niebla a través del manejo alternativo: Los agroecosistemas cafetaleros. Agroproductividad 2017, 10, 62-68.

74. Ortiz Ceballos, G.; Pineda-López, M.; del Rosario, M. Las Fincas de Café: Sitos de conservación in situ de biodiversidad. In Ecología, Manejo y Conservación de los Ecosistemas de Montaña en México; Sanchez, L., Fletcher, F., Eds.; CONABIO: México City, México, 2008; pp. 231-249.

75. Montagnini, F.; Nair, P. Carbon sequestration: An underexploited environmental benefit of agroforestry systems. Agrofor. Syst. 2004, 61, 281-295.

76. Young, A. Agroforestry for Soil Management.; Number Ed. 2; CAB International: Wallingford, UK, 1997.

77. Peeters, L.Y.; Soto-Pinto, L.; Perales, H.; Montoya, G.; Ishiki, M. Coffee production, timber, and firewood in traditional and Inga-shaded plantations in Southern Mexico. Agric. Ecosyst. Environ. 2003, 95, 481-493. [CrossRef]

78. Ordoñez Díaz, J.A.B. Captura de carbono en un bosque templado: El caso de San Juan Nuevo, Michoacán.; INE-SEMARNAP: Mexico City, Mexico, 1999.

79. Fournier, O. Fijación de carbono y diversidad biológica en el agroecosistema cafetero. In Simposio de Caficultura Latinoamericana; Inter-American Institute for Cooperation on Agriculture, Ed.; IICA: San Salvador, El Salvador, 1995.

80. López, A.; Schlönvoigt, A.; Ibrahim, M.; Kleinn, C.; Kanninen, M. Cuantificación del carbono almacenado en el suelo de un sistema silvopastoril en la zona Atlántica de Costa Rica. Agroforestería En Las Américas 1999, 6,51 .

81. Brigido, J.G.; Nikolskii, I.; Terrazas, L.; Herrera, S.S. Estimación del impacto del cambio climático sobre fertilidad del suelo y productividad de café en Veracruz, México. Tecnol. y Cienc. del Agua 2015, 6, 101-116.

82. Sánchez Hernández, S.; Briseño, M.; Alfonso, M.; Hernández, G.; Vidal, R. Diversificación de la sombra tradicional de cafetales en Veracruz mediante especies maderables. Rev. Mex. De Cienc. For. 2017, 8, 7-18.

83. Chave, J.; Condit, R.; Aguilar, S.; Hernandez, A.; Lao, S.; Perez, R. Error propagation and scaling for tropical forest biomass estimates. Philos. Trans. R. Soc. Lond. Ser. B Biol. Sci. 2004, 359, 409-420. [CrossRef]

84. Clark, D.A. Detecting tropical forests' responses to global climatic and atmospheric change: Current challenges and a way forward. Biotropica 2007, 39, 4-19. [CrossRef]

85. Chave, J.; Andalo, C.; Brown, S.; Cairns, M.A.; Chambers, J.Q.; Eamus, D.; Fölster, H.; Fromard, F.; Higuchi, N.; Kira, T. Tree allometry and improved estimation of carbon stocks and balance in tropical forests. Oecologia 2005, 145, 87-99. [CrossRef] [PubMed]

86. Sierra, C.A.; Valle, J.I.d.; Orrego, S.A.; Moreno, F.H.; Harmon, M.E.; Zapata, M.; Colorado, G.J.; Herrera, M.A.; Lara, W.; Restrepo, D.E. Total carbon stocks in a tropical forest landscape of thePorce region, Colombia. For. Ecol. Manag. 2007, 243, 299-309. [CrossRef]

87. Litton, C.M.; Boone Kauffman, J. Allometric models for predicting aboveground biomass in two widespread woody plants in Hawaii. Biotropica 2008, 40, 313-320. [CrossRef] 